\title{
THE OBJECTS OF CRIMINAL PROCEDURE AS THEY APPEAR TO A FRENCH PROSECUTING OFFICER.
}

An imperial decree, passed in France in I8Io and still in force, provides that, after the long summer vacation, all the Courts of Appeal shall be formally opened in the presence of the various chambers, and an address pronounced by the attorney general (procurcur sénciral) of the department or an advocate deputed by lim for the purpose, after which the chief justice (premier présidcnt) shall renew his oath of office, and all the advocates present shall renew theirs. It is an imposing ceremonial. The Judges appear in red gowns; the lawyers in black. The civil, military, and religious anthorities of the place are introduced in their appropriate costumes, filing into the court room in an order of procedure established by rule. The main subject of the address is selected by the orator of the occasion, but he is bound in the course of it to remind the advocates and attorneys of their professional duties, and to commemorate the attainments-and the services of distinguished members of the bar who may have died during the preceding year.

This regulation has been the source of many valuable contributions to the growth and improvement of French jurisprudence, and to a man who has anything to suggest in that direction affords a remarkable opportunity to bring it to public attention under favorable circumstances.

At the opening of the Court of Appeals of Aix, on October 16, I902, an interesting address of this nature was pronounced by Dr. Gabriel Chervet, one of the Assistant Attorneys General (substitut du Procurcur Général), which fairly represents the present attitude in France of what may be called the sentimental school of modern penology. He took for his special subject the gradual softening of criminal justice in recent times, and the tendency of our day to measure punishment less by the crime than by the circumstances attending its commission.

The Penal Code of Napoleon, he said, bore and still retained the rude stamp of his dominating, pitiless, and re-actionary disposition. Its object was vengeance. Charles Lucas stood out as the 
first Frenchman to bring to the knowledge of his countrymen or to initiate the science of Penology. This was within the past half century. Its main principle might be said to be the individualization of punishment. Lombroso's position that there were crimes, but no criminals, was no doubt too extreme. Man could not be now measured by the standards appropriate to his ancestors of the neolithic age. To the school of penology, favored by Turin, had come to be opposed the school of Lyons, whose chief was Dr. Lacassagne. His theory is that although the wrong doer may be so constituted as to be subject to no legitimate individual responsibility, he cannot free himself from the consequences of his social environment. In a word, he is responsible socially. But how far and in what manner? To answer these questions, Lacassagne would divide criminals into three classes:

"I. Those criminal in fecling. These are the born criminals of Lombroso: relatively few. They are incorrigible and dangerous in the highest degree. They must be eliminated from the social environment in which they are scattered. In default of capital punishment, which remains with us the 'supreme and desperate remedy'; they must be transported, never to return.

2. Those criminal in thought. These are the insane criminals who should be confined in special asylums.

3. Those criminals in acts. These are the most numerous; those with whom our courts have oftenest to deal. They may themselves be subdivided into professionals (or habitual criminals) and accidentals (or occasional criminals). They are susceptible of improvement. For them there must be a penal system permitting (I) keeping them out of mischief (preventive measures, substitutes for punishment): (2) re-classing them in society (reformatory measures, complements of punishment). It is for them that we must admit the legitimacy of penalty; not a chastising-penalty, but an improving-penalty.

These are sulbstantially the conclusions reached, aiter a remarkable discussion between II. Endrico Ferri and Dr. Etienne Martin, assistant of Dr. Lacassagne, by the Congress of Criminal Anthropology held at the University of Amsterdam in September, IgOI." * * *

"The penal code of I8Io affirmed the principle 'To each wrong its penalty', and one of its principal cumpilers, Berlier, could say 'We have carefully sought to establish a just proportion between penalties and crimes.? Todlay the tendency is to assert this wholly different rule: 'To each wrong doer his penalty:' We must, it is declared, attach less importance to the objectic' $\mathcal{c}$ gravity of the misdeed than to the subjectic'e character of the wrong doer. $\mathrm{We}$ must take into account his nature, his temperament. his antecedents, the situation of his family. his heredity. the culacation which he has received and the surroundings in which he has lived. Is it 
not absurd to maintain that all murderers, all thieves, all sharpers, correspond to uniform types to which it is possible to apply the same rules and the same mode of repression?"

"The application of these principles has already been made by legislative reforms, of which the most noteworthy in France is undoubtedly the law of March 26, I89I, as to the mitigation and aggravation of penalties.* 'It is,' writes M. Saleilles, 'a law of penal individualization, pure and simple, by which one is made to look at the individual, not the deed. $* * *$ The legislator has determined that the magistrate should take into consideration not the gravity of the misdeed, but the chances of recovery for the individual; and then of what consequence is the misdeed?

But you know too well, Gentlemen, the achievement to which the name of Senator Bérenger has been justly attached, for me to dwell on it. I content myself with noting the results attained in ten years. In I890 there were on the average 75,000 convictions a year for a second offence. In 1900 the figures were reduced to 64,000 . In I 890 there were 150,000 persons convicted of a first off $\in$ nce. In I900 there were no more than 105,000. There is no need of commentary.

$I$ add that $M$. Bérenger intends to complete his reform. Following the suspension of penalty, he demands, by a new statute $\because$ hich he proposes, the suspension of prosecution, so that the :aristrate charged with the preliminary inquiry. (juge d'instruc$\therefore$ in), although finding the charges sustained, may render a simple juirgment of warning.

This system of warnings, pronounced either by the magisirate holding in private the preliminary inquiry, or by a formal judgment after a public trial, has been adopted in several countries.

The Italian penal code of 1889 (Art. 26) has instituted an admonition, the efficacy of which is secured by special provisions. The Spanish law authorizes the public or private reprimand (reprension publica-priz'ada). Germany, Switzerland (in the cantons of Vaud and Appenzel), Portugal, Russia even, permit analogous dispositions. In the United States, certain States (Iowa, Maryland, Missouri, Vermont, Virginia, Connecticut,) confer on the Govcrnor or a grand council, the right to accord a conditional pardon, immediately after sentence is pronounced. This pardon is conceded only on a parole given for good conduct, and is revocable by the same authority, if the condition is not scrupulously fulfilled.

In England, Mr. Howard Vincent, former director of criminal affairs at London and a member of Parliament, procured the adoption in I887 of the law known by the barbarous name of Probation of First Offenders. The magistrate examines into the affair, considers the charges, hears the defence; but after having found guilt established, he has the power not to proceed immediately to

*This is commonly known as the Loi Bérenger, it having been proposed by M. Bérenger, (who is a member of the Institute of France) in the Senate. 
sentence, if he deems the delinquent worthy of such favor; he may suspend judgment until the expiration of a variable term. The guilty man is then forthwith set at liberty, if not already in that condition, but he remains under the watch of a probation officer, whose duty it is to aid him to conduct himself honorably and prove himself worthy of a pardon. If it is found that he has not failed in this respect, during the time fixed by the judge, the prosecution is abandoned. Otherwise it is revived and the judge fixes the penalty to be imposed."

The jails provided in France for those accused or convicted of minor offences (maisons d'arrêt et de correction) have, in most cases, according to $M$. Chervet, little to recommend them. One he described which he had inspected, one summer, in Provence. The prisoners had the run of a large court-yard.

"Seated on one side, a guard, pipe in mouth, and newspaper in hand, was peacefully asleep. In the shady corners groups were collected. Two or three convicts with slow and rythmic motion were cracking almonds open with a sheep bone;-they represented those sentenced to labor. Others were turning over the greasy pages of a picture book drawn from the library of the quarter. One lying on his stomach was writing letters. Most were wholly unoccupied. There they. were, lying on the ground, asleep, or planning with one another perhaps, among friends, the next rascality to engage in after their discharge.

And this kind of spectacle evoked the celebrated ballad of Paul Verlaine

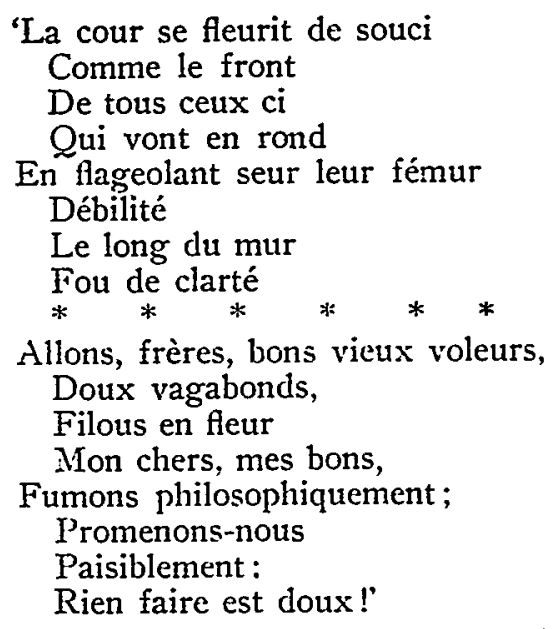

In fact, Gentlemen, for many of these weak, indolent. careless, and impressionable beings, whose moral sense has long been blunted by the hard knocks of life. the prison seems a good lodging and asylum where one finds true content in an atmosphere of repose. Unlooked for meetings, unexpected acquaintanceships, 
even the regularity imposed by a discipline not too severe, are powerful attractions to them.

For these degenerates, the punishment thus undergone is neither expiatory, nor exemplary, nor reformative; it is nothing; it is worse; precisely there is the stumbling block of the most praiseworthy attempts to prevent second offences, for the jail conducted in this way supports a living fire where is continually cooking a germ-broth of the most dangerous criminality. With such intimacies of intercourse tolerated, one might say organized, the jail-yard, the eatingrooms, the workshops, at times even the sleeping rooms, become true schoolrooms of crime. The professionals are its professors."

Legislation, M. Chervet added, has not been wanting to bring about a change in these conditions. The laws of 1875 and 1893 provided for the separation of those held for trial from those already convicted. The decree of November II, I885, provided proper regulations for the administration of prisons for those sentenced for short terms. "Unhappily, financial difficulties and the deplorable inertia of the departments have not yet permitted the transformation desired and directed by the legislator."

$M$. Chervet then turned to the consideration of the American plan of indeterminate sentence, which he was inclined to favor. The main objections urged against it he stated and examined as follows:

"I. The penalty, it is said, which is the sanction of the law, ought before everything to be the punishment of the offence. The triple end in view, prevention, reparation, example, demands that it be adequate to the breach of duty committed, and so, certain. To be just, it must be proportioned to the misdeed. The penal system which concerns itself exclusively with the improvement of the offender sacrifices to his individual interest the higher interest of public order and society.

This is the objection of the classic school. It appeals to me little, for if we set aside the outgrown conceptions of vengeance, sin, and expiation, what is the object of society in inflicting penalties? It is its preservation, its own defense, the necessity of maintaining the conditions constituting collective existence: law, and penalty, the sanction of law, are only means. If then it be shown that indeterminate sentences, better than punishments of predetermined duration. by effecting the improvement of the guilty, prevent second offenses, and diminish the criminal class, the argument disappears.

2. But, it is added, this system is finally summed up in a determination a posteriori, and this determination, which depends wholly on the opinions of administrative officials, escapes all control. Now the respect for individual liberty which should be the basis of all social organization, demands that a punishment depriving a man of liberty shall be pronounced only for a certain term, by impar- 
tial and able judges, with all the guarantees of independence and publicity established by law, under the direct and unceasing control of public opinion. For that guardian-like organization of criminal justice which is provided by our penal code, the American penologists substitute a bastard and indefinite system by which the liberty of convicts is given over to the good pleasure of a parcel of subalterns and irresponsible jailers.

This is incontestably the most serious objection which can be opposed to the thesis in question. It is evident that in the present state of our maners, our habits, and our prejudices, it would be difficult to acclimate among us so radical changes in the administration of criminal justice. However, it would be possible, while maintaining the essential principles of the reform, to bring to it certain amendments of a kind to render its application more conformable to our traditional ideas."

As such amendments, M. Chervet suggested that there might be two sentences in each case, by the same court: the first indeterminate; the second for a fixed term, or for release, passed after a report as to the conduct and character of the convict while imprisoned under the first. Or the sentence might be for a term not less than a certain period, nor longer than another period; its actual length to be determined later by a special board composed of the director of the prison, the attorney general, the police judge, and two citizens of high standing, such as professors of law, named by the government.

He then advocated the adoption of a measure proposed in the Franch Senate in I90I, by which the jury might accompany a verdict of guilty with a finding of circumstances of great mitigation (circonstances trìs atténuantes), in which case the punishment otherwise applicable to the crime would be reduced. A similar project had been brought forward in 1886 , and the government had consulted all the courts of appeal in regard to its merits. That of Aix, after considering a report from a committee of the bar on the subject, had responded unfavorably. M. Chervet begged leave to combat that conclusion.

"The reasons which determined your action then hardly appear to me decisive. The proposition, said the chairman of your committee. had for its object to put a stop to scanclalous acquittals; and this object it would not attain, for the jury when it renders these unfortunate verdicts yields almost always to influences exerted upon it by customs, by opinion, or still more by interest, by pity. Rarely would it have consented to inflict even a slight punishment on those who seemed to it rather victims than criminals.

Is this really so? I appeal to you who are Presidents of the assizes. Is it not a known fact, constanty attested, that jurors pre- 
occupy themselves above all with the punishment that will be pronounced? The provisions of Art. $342^{*}$ of the code of criminal procedure lave become a dead letter, and no one would dare to dream of reviving them. There is established in this respect a tacit accord between the court, the prosecution and the defence. Jurors are frankly made acquainted with the consequences of their verdicts, and many times if a doubt exists as to this in their minds, they ask the presiding judge to come to the jury room to enlighten them; going so far as to express their desire for a special indulgence in the application of the law. But if the minimum penalty appear to them out of proportion to the responsibility incumbent on the accused, then an acquittal follows:--an acquittal pronounced with regret and because between two bad solutions they have believed it best to. choose the least detestable.

There, Gentlemen, you must agree with me is the chief cause, not to say the only one, of the deplorable miscarriage of many prosecutions on charges of arson, bankruptcy, forgery, counterfeiting, etc. There too must be sought the motives of this absolving kind of legal procedure (jurisprudence absolutoire) which has grown up for crimes of passion, murders, or homicides, which jurors deplore as we all do, and which they would not hesitate to condemn, if they did not deem the inevitable result of imprisonment at hard labor or solitary confinement an excessive penalty."

In closing M. Chervet alluded thus to the duties of prosecuting officers towards the criminal:

"Gentlemen of the Bar. In a recent circular the Attorney General of the Court of Appeals of Paris recommended to his deputies to present, themselves, the defence of accused persons who had no counsel, and not to hesitate to disclose to the court circumstances of a nature leading to an acquittal, to a suspension of judgement, of a mitigation of penalty. This practice is followed here, without need of directions to that effect. Many a time, for my part, I have had the satisfaction of asking for indulgence, pity, pardon. Many a time I have joined myself to the committee for the defence of children brought to the bar, to pray the court to keep some interesting young culprit from the house of correction. Your bar, GentTemen, cannot be jealous of this loyal concurrence in your duties.

Do we not both pursue a common task-the search for truth? Do not our efforts tend towards the same ideal-justice? Are not our means the same,- good faith and free discussion?"

It may be added that this address evinces a familiarity with the current tenets of the different schools of penology which would be possessed by few American prosecuting officers.

*This requires the jurors to be warned that they fail in their duty when by thinking of the penalty prescribed, they consider the consequences to the accused of the verdict they are to render; their sole function being to decide if he is guilty or not guilty of the crime charged. 
There is in the Continental lawyer a more scholastic habit of mind than is possessed by his English or American brethren, and a stronger tendency to theorize. He reasons from codes, philosophically constructed. He, therefore, reasons on scientific lines. $\mathrm{He}$ is in close contact witl neighboring countries whose jurisprudence is allied to that of his own, and yet different from it. $\mathrm{He}$ is near enough to the round of annual and triennial and quinquennial congresses of penal legislation, anthropology, and public law, to catch the spirit of their thought. He reads their proceedings, and is stimulated by their discussions to original investigation of his own.

M. Chervet quotes frequently in his address from the Report of the last Congrès Pénitcntiaire International, held in Brussels in 1900. This is full of thoughtful and well-considered reflections on the subjects considered in his address. Our government will probably soon publish a compendium of its conclusions, prepared by Hon. Samuel J. Barrows, the chairman of the delegation from the United States, and every American lawyer interested in criminal procedure would find it well worth his study.

Simeon E. Baldwern. 